\title{
Alternative Primary and Secondary Education and Its Influence on Access to University Education and Self-Efficacy of Undergraduate Students in Nigeria
}

\author{
${ }^{1}$ Ishola Akindele Salami, ${ }^{2}$ Grace Chinenye Nweke \\ ${ }^{l}$ Early Childhood Education Unit Department of Teacher Education, University of Ibadan, Nigeria \\ ${ }^{2}$ Department of Special Education, University of Ibadan, Nigeria
}

\begin{abstract}
Formal education is of various levels in which the curriculum is designed in a spiral form; wherein a level is meant to be a prerequisite to the next level. When a given level of formal education suffers, its effects are always enormous on the next level. The idea of alternative educational systems also operates in Nigeria wherein, education are either provided by the government (public), individuals or organizations (private). These two forms of education produce students for university education. The quality of these schools could be accessed by examine their products in terms of access to university education, self-efficacy and academic performance at university level. This study adopted descriptive survey, and undergraduate students in 200 level in University of Ibadan were used as a case study. The results reveal that there is a significant difference among the number of undergraduate who attended public and private primary schools among others.
\end{abstract}

Keywords: Alternative education, Primary education, University education, Self-efficacy, academic performance.

\section{Introduction}

Education has been described as the bedrock of every society and tool for nation building. It is the vital instrument for social and economic mobility at the personal level and an instrument for transformation of society at the national level. Formal education is of various levels in which the curriculum is designed in a spiral form; wherein, a level is meant to be a prerequisite to the next level. This is done such that learning can really move from known to unknown and simple to complex. When a given level of formal education suffers, its effects are always enormous at other levels after it.

Education in Nigeria is nationally conceptualized not simply as the medium for cultural transmission but the main vehicle for accelerating individual, community and national development Kazeem \& Ige (2010). It is a mechanism through which the society generates the knowledge and skills required for its survival and sustenance. It is considered as an instrument for national development (FGN, 2004: section 1 sub-section 4a)

Primary education, the second level of Basic Education in Nigeria (FGN, 2004), is the level of education that develops in the individual the capacity to read, write and calculate. In other words, it helps to eradicate illiteracy, which is one of the strongest predictors of poverty (Bruns, Mingat \& Rakotamalala, 2003). Thus, Primary education is the only level of education that is available everywhere in both the developed and the developing countries as well as in urban and rural areas (Akinbote, Oduolowu \& Lawal, 2001). This explains why primary education is the largest sub-sector of any education system and offers the unique opportunity to contribute to the transformation of societies through the education of the young ones (UNESCO, 2001).

The early stage of a child is crucial to his emotional, behavioural, physical and mental development. Primary school education is responsible for the overall development of the child at the early stages of his life. Considering the fact that education is a preparation of life for secondary school education and University at large, primary school education serve as a foundation to any other educational level (Saidu \& Shuaibu, 2000).

The importance of primary education can therefore be seen in the sense that all beneficiaries of the other levels of education by necessity have to pass through this level (Oni, 2008). What this means is that primary education defined as the education given in an institution for children aged 6-11 years plus constitutes the bedrock upon, which the entire education system is built. Indeed, the success and failure of the entire education system are determined by it and it is at the heart of the concept of basic education also defined as universalisation of access of education (Oni, 2008).

Secondary education is the next level of education after the primary. The language of instruction for all secondary school grades is English, except for special courses that require another language. Students study 9 to 12 subjects, including a core group that consists of mathematics, English language, a major Nigeria language (Hausa, Igbo, or Yoruba), social studies, creative arts, integrated science, practical agriculture, religious studies (Christianity or Islam), and physical education. Depending on the school, students may select electives from 
courses such as introduction to technology, home economics, business studies, local crafts, and foreign languages (often Arabic or French). In their twelfth year, students take the Senior School Certificate Examination (SSCE).

\section{Mode of Operations of Primary and Secondary Educational Systems in Nigeria}

According to the National Policy on Education (FGN, 1981 to 2004), the provision of primary and secondary education have always been in the hands of the government and private individuals. There are two types of these school systems in Nigeria: public and private schools. The public is provided by the government while the private is provided by private individuals, organizations and institutions.

Private schools are exclusive; those who pursue education in these institutions must pay for the services they enjoy whereas, public schools at least, are open to all - the rich and poor. Considering the fact that public schools do not enjoy a lot of public confidence at the moment, owing to decaying infrastructure and years of neglect, it is likely that parents favour private schools as viable alternative to public schools. Most likely, the state of public schools could be as a result of the fact that most government functionaries have their children and/or wards in either the private schools or schooling outside the country.

Starting with the colonial period, Nigeria, having been colonized by Britain adopted the British form of education, which consists of pre-school, primary, secondary and higher education (Fabunmi, 2005).

\section{Primary School Education}

In Nigeria, children start attending primary schools when they are around 6 years old and spend 5 or 6 years to graduate at the age 11 or 12 years (FGN, 2004). Those that finish earlier are the children that attended private schools where most of them started before age 6 and graduate after the fifth year. When they finish the six years programme, they are awarded the First School Leaving Certificate, which, in combination with the common entrance examination results, fulfil the formal requirements for secondary school education. As said earlier, there are both private and public primary schools. The private ones are considered better than the public by the people because they are of the opinion that; the teaching and learning activities are monitored; facilities are provided than the public schools; the learning outcomes in private schools are most of the cases, better than that of public schools. Actually, private schools are profit-oriented schools and in other to maximise their profits, most of them employ untrained teachers that will earn less, most materials claimed to have been provided are either not working, not adequate or the teacher cannot make effective use of them and rote learning, memorization and drilling method of teaching are used in other to have better results. Most of the practices in private primary schools are developmentally inappropriate (Copple and Bredekamp, 2009). Since Nigerian government proclaim free basic education for the citizenry, public primary schools are not profit-oriented schools; hence, many could afford it. But facilities are not provided; qualified teachers are employed but they are not monitored and motivated. Both private and public primary schools produce pupils for the secondary level of education.

\section{Secondary School Education}

Pupils who emerge successful at the primary school level move to the secondary level. The first phase of the secondary education, which lasts for three years, is provided at the Junior Secondary Schools (FGN, 2004). At the end of these three years, students sit for Junior Secondary School Examination (JSSE) and the successful ones are awarded the Junior Secondary School Certificate (JSSC). A successful completion of the JSS is a prerequisite for the second phase - the Senior Secondary School (SSS), which also lasts for three years. At the end of this period, students obtain the Senior Secondary School Certificate (SSSC) after writing and passing the final examination, which is the Senior Secondary School Examination. The SSSC is equivalent to the former West African School Certificate (WASC). As it operates in primary school level, there are both private and public secondary schools too. The features of the secondary schools (private versus public) are just the same as that of primary schools.

Regardless of which secondary schools the students attend, all students who wish to study at a university level must have at least 5 credits (in not more than two exams) out of the subjects they entered for in the SSS examination(s). These subjects must be relevant to the courses they want to study and should include credits in English language (especially in Humanities), Mathematics (especially if one wishes to study a science course) and a science subject. In addition, they have to pass the Unified Tertiary Matriculation Examination (UTME), which is conducted by the Joint Admission and Matriculation Board (JAMB).

The need for development is more glaring in Africa, especially in Nigeria, going by the apparent decay in the educational and school systems; hence the introduction of Private Partnership Initiative in education by the federal government in 1999. This development opened doors for more private investors to establish schools in the country to complement government's efforts to meet the increasing demand for qualitative education in Nigeria. 
However, the sad aspect of the policy is that the system has been abused by some investors who came to the sector merely for money. Moreover, many people who knew nothing about education now appear to be finding their ways into the system as proprietors(resses) at both primary and secondary educational levels. There has been an emerging era of proliferation of substandard primary and secondary schools across the country. Today, one finds many of these schools in a room and parlour apartments, and one may begin to wonder whether or not government is aware of the existence of these schools in the first place and the fact that education sector has become a free for all enterprise. The most worrisome of this issue is the ability of both public and private primary and secondary schools in Nigeria to prepare the students for university education, the selfefficacy about university education, and the academic performance of the students that attended public and private basic and senior secondary education at the university level. If this is revealed, it will enable all the tiers of government in Nigeria to attend to the needs of the public schools where the majority of the citizens could afford.

\section{Objectives of the Study}

1. To find out the extent to which alternative education influences accessibility into higher education, most especially, university education in Nigeria.

2. To investigate the extent to which alternative education prepares Nigerian students for university education in terms of self-efficacy and academic performance.

\section{Research Questions}

1. Of the undergraduate students, what proportion had their primary and/or secondary education in public schools and private schools?

2. Is there significant difference in the self-efficacy about university academic activities between undergraduate students who attended public and private primary schools?

3. Is there significant difference in the self-efficacy about university academic activities between undergraduate students who attended public and private secondary schools?

4. Is there significant difference in academic achievement of undergraduate students who attended public and private primary schools?

5. Is there significant difference in academic achievement of undergraduate students who attended public and private secondary schools?

\section{Research Methodology}

This study adopted ex-post facto type of causal-comparative research design to investigate the influence alternative educational system could have on accessibility, self-efficacy and academic performance of students in University education. The target population of the study is the entire undergraduate students in public universities in Nigeria. Public universities were targeted because the level of biased admission in these institutions is less, compared to the private ones. University of Ibadan, the premier university and highly esteemed university in Nigeria as at today, was used as a case study. The study involved 941 students in the 200 level of their programmes in 53 departments across 16 faculties, colleges and institutes in the University. Multistage sampling technique was used in the study. All the faculties, colleges and institutes were involved and stratified random sampling was used to select the departments. Students who participated in the study were randomly selected in the departments through their list. Almost $27 \%$ of this students attended public primary schools while $73 \%$ attended private primary schools. About $49 \%$ attended public secondary schools while $51 \%$ attended private secondary schools. A self-designed instrument titled 'Alternative Primary and Secondary Education and University Education' questionnaire was used to gather the data. The instrument was divided into three sections namely: demographic section where information about primary and secondary education were sought; self-efficacy section with 10 items measuring the self-efficacy of the students about academic activities in the university and, academic performance section where the Cumulative Grade Point Average (CGPA) of the students were sought. A total of 17 items were in the questionnaire. Four weeks was used to administer the instrument all over the university and the data collected was analysed using both descriptive and inferential statistics: frequency count and percentage were the descriptive statistics used while the inferential statistics were chi-square, t-test and correlation

\section{Results}

The results of this study are presented in the order of the research questions. Research Question 1: Of the undergraduate students, what proportion had their primary and/or secondary education in public schools and private schools? 
Table 1a: Summary of Chi-square $\left(\chi^{2}\right)$ Showing Difference between Undergraduates who Attended Public and Private Primary Schools

\begin{tabular}{rcccccr}
\hline Type of Primary School & Observd. & Expectd. & $\chi^{2}$ & df & Sig. & Remark \\
\hline Public & 254 & 470.5 & & & \\
Private & 687 & 470.5 & 199.24 & 1 & .000 & Significant \\
\hline
\end{tabular}

Table 1a reveals that there is a significant difference among the number of undergraduate who attended public and private primary schools $\left(\chi^{2}=199.24\right.$; $\left.\mathrm{df}=1 ; \mathrm{P}<0.05\right)$. Those who attended private primary schools are more (687) than those that attended public primary schools (254). This information is depicted in figure 1 below.

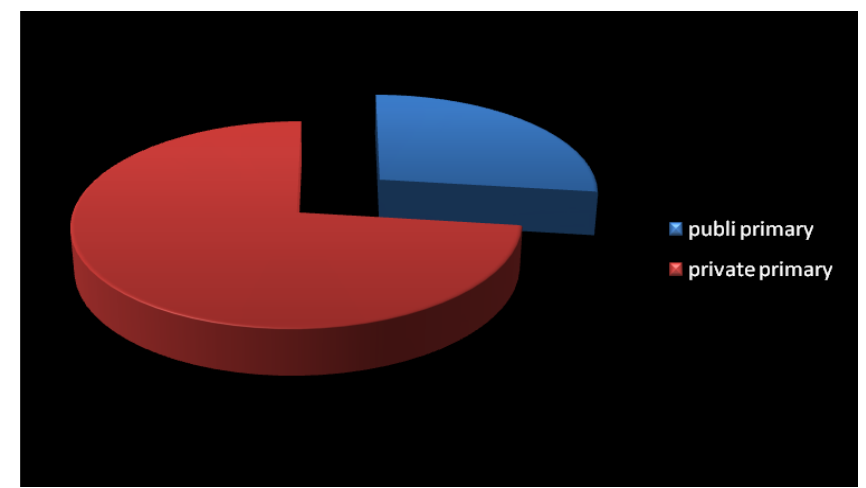

Fig.1: Pie Chart Showing Distribution of Undergraduates According to Type of Primary School Attended

This finding confirms the pronouncement of Federal Government of Nigeria in the National policy on Education (FGN, 2004; section 4, sub-section 19L) that private agencies, communities and individuals are welcomed in the provision of primary education in the country, which led to the alternative primary schools called Private Primary Schools. The finding was expected because of the perception of Nigerians about public primary schools as schools that lack everything that can bring about meaningful development in the child, which affected its enrolment.

Average Nigerians, even those who cannot afford the charges of private primary schools still prefer to enrol their children in private nursery and primary schools. Many prefer to enrol their children in a private school with no qualified teachers, no materials and space for the child to play rather than take the child to a public school where there are qualified teachers and enough space. It therefore seems that many parents share some level of joy in the fact that their children are in private schools irrespective of the quality of the schools. Those who enrol their children in public primary schools are the ones who are in the least poverty ladder, those who want to give formal education to their house helps and those who are in villages where there is no private school or the available ones are too expensive than they can afford. Therefore, the number of Nigerian children attending public primary schools is too low compared to those attending private schools. In fact, to have recorded $27 \%$ of those in University of Ibadan as those who attended public primary school is to establish that these schools are not as bad as perceived by Nigerians. A casual visit to public schools in Nigeria will reveal the extent to which these schools have deteriorated. Educational facilities at all levels are not in a good shape; schools are littered with battered structures; non-functioning equipment (where they are available at all); dilapidated classroom buildings; over-crowded classrooms; inadequate manpower in quantity and quality; instability in the academic calendar owing to strikes; very low teacher (staff) morale due to poor remuneration and working conditions. Still, the knowledge acquired in these schools gave them admission into the Premier University in the country.

Table 1b: Summary of Chi-square $\left(\chi^{2}\right)$ Showing Difference between Undergraduates that Attended Public and Private Secondary Schools

\begin{tabular}{ccccccc}
\hline Type of Secondary School & Observd. & Expectd. & $\chi^{2}$ & df & Sig. & Remark \\
\hline Public Sec. school & 448 & 470.5 & & & & \\
Private Sec. school & 493 & 470.5 & 2.16 & 1 & .206 & Not Sig. \\
\hline
\end{tabular}

Table $1 \mathrm{~b}$ shows that there is no significant difference between the number of undergraduates who attended public and private secondary schools in Nigeria $\left(\chi^{2}=2.16 ; \mathrm{df}=1 ; \mathrm{P}>0.05\right)$. While $48 \%$ of the students attended public secondary schools, $52 \%$ attended private ones. The difference (4\%) is shown not to be statistically significant. As in the case of primary education, government also welcomes the involvement of 
agencies, community and private individuals in the establishment and management of secondary education (FGN, 2004: section 5, sub-section 26). Figure 2 presents this information in a chart.

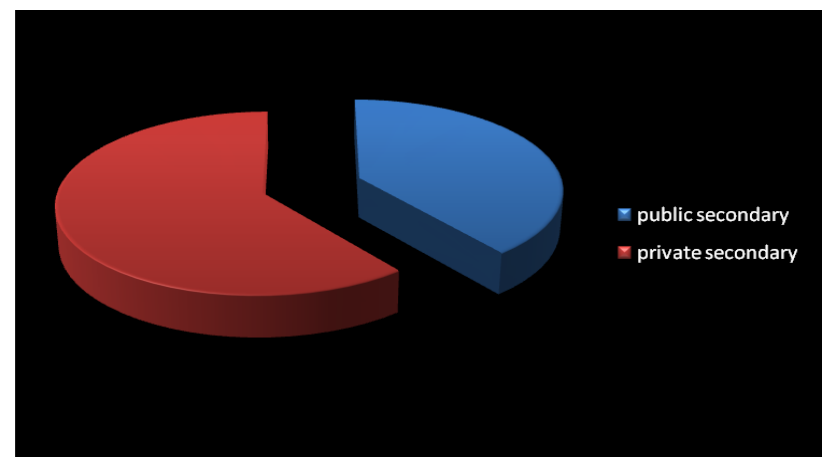

Fig. 2: Pie Chart Showing Distribution of Undergraduates According to Type of secondary

\section{School Attended}

The perception of Nigerians about public secondary school is almost the same as that of primary schools. Anybody who can afford it will surely enrol their children in private secondary schools. The feeling, most of the time about shortcomings of these schools makes parents want to go for the private ones. The effect of these parents' attitude towards public secondary schools is not so felt like that of the primary schools because many parents cannot afford the cost of the private secondary schools. Besides, the private secondary schools available are not as many when compared with private primary schools. This could have accounted for the increase in the number of undergraduate students who attended public secondary schools $(48 \%)$. The next is now to establish if the preference for private primary and secondary schools really translates to effectiveness at the university level. This will be determined by the performances of their products in the university in terms of self-efficacy about academic activities and their academic performance as measured by their grade points at the end of their first year.

Research Question 2: Is there significant difference in the self-efficacy about university academic activities between undergraduate students who attended public and private primary schools?

Table 2: Summary of t-test Analysis Showing Difference in the Self-efficacy of Undergraduates who Attended Public and Private Primary Schools

\begin{tabular}{|c|c|c|c|c|c|c|c|}
\hline Variables & $\mathbf{N}$ & Mean & Std.D & $\mathbf{t}$ & df & Sig. & Remark \\
\hline SELF-EFFICACY OF UNDERG. & & & & \multirow{3}{*}{1.315} & \multirow{3}{*}{925} & \multirow{3}{*}{.189} & \multirow{3}{*}{ Not Sig. } \\
\hline Public Primary School Attendees & 241 & 33.42 & 6.39 & & & & \\
\hline Private Primary School Attendees & 686 & 32.75 & 6.96 & & & & \\
\hline
\end{tabular}

Note: The Self-Efficacy scores of 14 students were not complete and hence removed.

Table 2 reveals that though those students who attended public primary schools have a higher self-efficacy mean score (33.4) than those who attended private primary schools; the difference between them is not statistically significant $(\mathrm{t}=1.32 ; \mathrm{df}=925 ; \mathrm{P}>0.05)$. This implies that the self-efficacy of both categories of students about university academic activities is almost the same. This finding further confirms that public primary schools are not as bad as Nigerian populace have taken them to be. It is now confirmed that the self-efficacy of those who attended public primary schools about the university academic activities is as good as that of those who attended private secondary schools.

This could have been the case because though, the public primary schools lack good environment and facilities but they are so rich in quality teachers compared to the private schools. The least qualification of the primary school teachers is Nigeria Certificate in Education (TRCN, 2002) and some of the teachers have up to Masters degree. But, in the case of private primary schools, since the major aim of providing this education is to make profit, less qualified teachers are employed because fewer amounts will be paid them. The fact still remains that no matter what facilities and resources are provided in school; effective teaching/learning can only happen with good teachers.

Research Question 3: Is there significant difference in the self-efficacy about university academic activities between undergraduate students who attended public and private secondary schools? 
Alternative Primary and Secondary Education and Its Influence on Access to University Education

Table 3: Summary of t-test Analysis Showing Difference in the Self-efficacy of Undergraduates who Attended Public and Private Secondary Schools

\begin{tabular}{lccccccc}
\hline Variables & N & Mean & Std.D & t & df & Sig. & Remark \\
\hline $\begin{array}{l}\text { SELF-EFFICACY OF UNDERG. } \\
\text { Public Secondary School Attendees }\end{array}$ & 432 & 33.25 & 6.67 & & & & \\
& & & & 1.149 & 911 & .251 & Not Sig. \\
Private Secondary School Attendees & 481 & 32.73 & 7.02 & & & & \\
\hline
\end{tabular}

Note: The Self-Efficacy scores of 28 students were not complete and hence removed.

Table 3 reveals that there is no significant difference in the self-efficacy about university academic activities of undergraduates who attended public secondary schools and those who attended private ones $(\mathrm{t}=1.15 ; \mathrm{df}=911$; $\mathrm{P}>0.05$ ). This finding corroborates the first one previously discussed that the self-efficacy of the undergraduates who attended private primary schools is not significantly different from those who attended public primary schools.

This finding could have been that that the public secondary schools also prepare the students for further education almost as equally done by the highly costly private secondary schools irrespective of inadequate resources facing the government-owned schools. The first reason that comes to mind for this is the quality of school activities going on in the public schools which must have been master minded by the teachers. One thing the government ensures in the public secondary schools is that trained, certified and professional teachers are employed. Many of these teachers know what it requires to give all round development to the students and they must have been putting their knowledge to use as expected. Unlike what operates in the private secondary schools where all sorts of teachers permeate; those who are just school certificate holders with good results; those with Ordinary National Diploma; those with Higher National Diploma or degree in fields not related to education and the likes. These set of 'teachers' are employed in private secondary schools so that proprietor will pay less and maximise their profit. The best these kinds of teachers can do is encourage cognitive development of the students through rote learning and memorization of facts. In some cases resources are provided but the teachers cannot make use of them for effective teaching since they are not trained to do so; and other cases are when most of the displayed learning resources are window dressings which are not functioning.

Research Question 4: Is there significant difference in academic achievement of undergraduate students who attended public and private primary schools?

Table 4: Summary of t-test Analysis Showing Difference in the Grade-Points Average (GPA) of Undergraduates that Attended Public and Private Primary Schools

\begin{tabular}{|c|c|c|c|c|c|c|c|}
\hline Variables & $\mathbf{N}$ & Mean & Std.D & $t$ & df & Sig. & Remark \\
\hline $\begin{array}{l}\text { GPA OF UNDERGRADUATES. } \\
\text { Public Primary School Attendees }\end{array}$ & 241 & 4.61 & 1.24 & & & & \\
\hline Private Primary School Attendees & 687 & 4.67 & 1.07 & -0.664 & 926 & .507 & Not Sig. \\
\hline
\end{tabular}

Note: The GPA scores of 13 students were not supplied, hence removed.

Table 4 shows that there is no significant difference between the grade-point average of undergraduates who attended public primary schools and those that attended private ones $(t=-0.66 ; \mathrm{df}=926 ; \mathrm{P}>0.05)$. It should be made clear here that the university used as a case study here- University of Ibadan operates 7 points grade level system wherein in 4.6 is where second class upper division begins. This high score must have been recorded after the first year because of the quality of admission the University did in 2009/2010 session. The University is one of the very first to start post-UTME examination for prospective students.

The finding that those undergraduates who attended public primary school were able to score almost as high as those that attended private primary school further confirms the good work those teachers in public schools are doing without the necessary resources. This is not to say that the teachers in private schools are not working, most especially with the GPA of their students at the university level; but no one will expect those undergraduate students who attended public primary schools to perform as good as this study has shown. This is simply because almost all needed resources are not available except the dilapidated buildings, the teachers and the pupils. Every other resource is lacking. Many private primary schools are able to make available, at least the basic resources for teaching and learning, though quality not assured; teachers are closely monitored and supervised and little collaborations with the parents are sometimes ensured.

Research Question 5: Is there significant difference in academic achievement of undergraduate students who attended public and private secondary schools? 
Alternative Primary and Secondary Education and Its Influence on Access to University Education

Table 5: Summary of t-test Analysis Showing Difference in the Grade-Points Average (GPA) of Undergraduates that Attended Public and Private Secondary Schools

\begin{tabular}{|c|c|c|c|c|c|c|c|}
\hline Variables & $\mathbf{N}$ & Mean & Std.D & $\mathbf{t}$ & df & Sig. & Remark \\
\hline GPA OF UNDERGRADUATES. & & & & \multirow{3}{*}{-1.95} & \multirow{3}{*}{912} & \multirow{3}{*}{.052} & \multirow{3}{*}{ Not Sig. } \\
\hline Public Secondary School Attendees & 432 & 4.58 & 1.27 & & & & \\
\hline Private Secondary School Attendees & 482 & 4.72 & .93 & & & & \\
\hline
\end{tabular}

Note: The GPA scores of 13 students were not supplied, hence removed.

Table 5 shows that there is no significant difference between undergraduates who attended public and private secondary schools in the grade point average $(\mathrm{t}=1.95 ; \mathrm{df}=912 ; \mathrm{p}>0.05)$. This implies that the academic achievements of undergraduates who attended public secondary school is not statistically different from those that attended private secondary schools.

As discuss earlier, this could be as a result of the fact that the preparation given at the public secondary school level is also effective enough to equip the students for further academic activities. Though, most of the needed learning resources are not provided, but because the teachers are trained on how to improvise, most of the time they do find alternatives ways to make their teaching effective. In the private schools where some of these resources are provided, there is no assurance they are effectively put to use. Moreover, another serious factor about private schools is the method of teaching common to them-memorisation. Whatever learnt through memorisation hardly stands the test of time. That is why whatever learnt in the university is based on a very weak foundation. Also, most of the children of the average and the rich parents are the ones patronizing private schools. If not for some of them who are strictly handled, there are lots of distractions for them in their academic activities-'sophisticated toys' in the name of technology; unnecessary travelling and visitations and too much of social activities. Imagine a student watching a movie through the mobile phone while in a lecture. All these might account for their inability to perform as expected.

\section{Summary of Findings}

Based on the analysis and discussions done, the following are the summary of the findings:

* The number of undergraduate students who attended private primary schools is significantly more that those who attended public primary schools. This implies that private primary school products gain admission to the university than the public primary school products.

* There is no significant difference between the number of undergraduate students who attended private secondary schools and those that attended public secondary schools.

* There is no significant difference in the self-efficacy about university academic activities of undergraduates who attended public primary schools and those who attended private ones.

* There is no significant difference in the self-efficacy about university academic activities of undergraduates who attended public secondary schools and those who attended private ones.

* There is no significant difference between the grade-point-averages of undergraduates who attended public primary schools and those that attended private ones.

* There is no significant difference between undergraduates that attended public and private secondary schools in their grade-point-averages.

\section{Conclusion}

The alternative Basic and Secondary educational systems in Nigeria have almost the same level of effectiveness. This is clearly against the opinion of many Nigerians who have held tenaciously that private basic and secondary schools are doing far better than the public ones in the total development of the younger ones. Many of these parents pay through their nose, the charges of the private schools. Some private schools (Preschool, primary and secondary inclusive), charge as much as a million and half naira per academic section while the public schools still assume free education. Both the public and private schools have their strength and weaknesses; while public schools have qualified and professional teachers and lack every other learning resource; few private schools have resources, supervision and monitoring but many of them parade unqualified and unprofessional teachers and none functioning resources. Students in Nigeria would have been performing excellently if only the government can strengthen the public schools with learning resources, adequate supervision and monitoring of the teachers.

\section{Recommendations}

Based on the findings of this study, the following recommendations are proffered:

$\checkmark$ There should be a mechanism put in place by the Ministry of Education, the Federal Government of Nigeria and interested organisations that will ensure availability of learning resources in the pre- 
school, basic and secondary schools in Nigeria. If this is well planned, not only will it bring about availability of resources but, also, provide job opportunity for many educators in the country.

$\checkmark$ It will not be enough to make resources available in the schools but it must be ensured that they are put to proper use. Therefore, to ensure sustainability and utilisation; there should be close monitoring and supervision of the schools. For this to work better; there should be collaborations between all the public schools and the community where they are sited to this effect.

$\checkmark$ There is the need to maintain the minimum standards for the establishment of schools in Nigeria. These standards have been identified; what is left now is proper implementation for both the public and the private schools. Every Nigerian could be made a watch dog by ensuring that the standards are made known to the populace and give room for genuine complaints which will be promptly attended to by the concerned government agency.

If all these are done, the standard of the public schools will be enhanced and this will have positive effects on their productivity and, automatically, private schools owners who will want to remain in business will follow suit.

\section{REFERENCES}

[1]. Akinbote, O. (2001). The Nigerian Primary schoolteachers: Angels of instruction or devils of destruction? Nigerian Journal of Educational Philosophy Vii (1) 35-40.

[2]. Bruns, B. Mingart, A. \& Rakotomalala R. (2003). Achieving Universal Primary Education by 2015: A chance for Every Child. Washington, D. C. the World Bank

[3]. Copple C. and Bredekamp S. (2009). Developmentally Appropriate Practice in Early Childhood Programs: Serving children from birth through age 8. National Association for the Education of Young Children (NAEYC), Washington DC, USA

[4]. Fabunmi, M. (2005): Historical Analysis of Educational Policy Formulation in Nigeria: Implications for Educational Planning and Policy, International Journal of African \& African American Studies, Vol. 4, No.2

[5]. Federal Government of Nigeria (2004). National Policy on Education. $4^{\text {th }}$ ed. NERDC, Lagos, Nigeria.

[6]. Kazeem, K. and Ige, O. (2010). Redressing the Growing Concern of the Education Sector in Nigeria. Edo Journal of Counselling Vol. 3, No. 1

[7]. Oni, J.O. (2008). Universality of primary education in Nigeria: Trends and issues. Int. J. Afr. Am. Stud., 7: $24-31$.

[8]. Saidu, Shuaibu (2000). Primary School Education: A Preparation for Secondary Education. Nigerian Journal of Curriculum and Instruction Vol. 9, No. 4.

[9]. UNESCO (2001). Primary Education: The core of development and progress. UNESCO Education Webmaster. 